DOI: $10.4274 /$ tpa.46.34

\title{
Ergenlerde beslenme
}

\section{Adolescent nutrition}

Tülay Erkan

Istanbul Üniversitesi Cerrahpaşa Tıp Fakültesi, Çocuk Gastroenteroloji, Hepatoloji ve Beslenme Bilim Dall, İstanbul, Türkiye

\section{Özet}

Ergenlik dönemi, büyüme ve gelişmenin en hızlı olduğu, çocukluktan erişkinliğe geçişi kapsayan önemli bir dönemdir. Bu dönemdeki fiziksel değişiklikler bedenin besin gereksinimlerini de değiştirmektedir. Enerji, protein, vitamin ve mineral gereksinimi arttığı gibi, iştah da artmıştır. Bu dönemde yeme alışkanlıkları ve besin seçimlerinde de değişiklik olmaktadır. Hayat boyu sürecek beslenme alışkanlıkları ergenlik döneminde yerleşir. Ergenlik döneminde yetersiz beslenme ya da kötü beslenme alışkanlıkları sonucunda ileriki yıllarda osteoporoz, şişmanlık, hiperlipidemi, cinsel gelişimde gecikme, kalp-damar hastalıkları ve kanser önemli sorun olarak karşımıza çıkar. Ergen beslenmesini değerlendirirken normal koşullarda günlük alması gereken miktarların bilinmesi gerekir. Dolayısıyla günlük beslenme şekli ve içeriği öyküde mutlaka sorgulanmalıdır. Her grup besini içeren sağlıklı bir diyet ve düzenli yapılan fizik egzersiz ergenlerin sağlıklı büyüme ve gelişmesini sağlayacaktır. (Türk Ped Arş 2011; 46 Özel Sayl: 49-53)

Anahtar sözcükler: Beslenme gereksinimleri, egzersiz, ergenlik, yeme alışkanlıkları

\section{Summary}

Adolescence is an important period, being the period of most rapid growth and development and covering the transition from childhood to adulthood. Physical changes change the body's nutritional needs in this period. Energy, protein, vitamins and minerals needs increase, as well as appetite. During this period there is a change in eating habits and nutritional selections. Lifelong eating habits settle during adolescence. Inadequate nutrition or poor eating habits in adolescence may cause major problems like osteoporosis, obesity, hyperlipidemia, delayed sexual development, cardiovascular disease and cancer in later years. When evaluating adolescent nutrition, required daily amounts under normal conditions should be known. Therefore, the shape and content of the daily diet should be questioned in the history. A healthy diet which contains each group of nutrients and a lifestyle with regular physical exercise will induce healthy growth and development of adolescents. (Turk Arch Ped 2011; 46 Suppl: 49-53)

Key words: Nutritional needs, physical exercise, Adolescence, eating habits

\section{Giriş}

Ergenlik dönemi, büyüme ve gelişmenin en hızlı olduğu, çocukluktan erişkinliğe geçişi kapsayan önemli bir dönemdir (1). Ergenlik puberte ile başlamaktadır. Puberte kızlarda genel olarak 8-13 yaşlarında, erkeklerde ise 9-14 yaşlarında başlamaktadır. Dünya Sağlık Örgütü $10-19$ yaş grubunu ergenlik dönemi olarak tanımlamaktadır (1). Bu dönemdeki fiziksel değişiklikler bedenin besin gereksinimlerini de değiştirmektedir (Tablo 1). Enerji, protein, vitamin ve mineral gereksinimi arttığı gibi, iştah da bu dönemde artmıştır. Dolayısıyla besin seçimleri çok dikkatlice yapılmalıdır. Fiziksel değişikliklerle birlikte bu dönemde yeme alışanlıkları ve besin seçimlerinde de değişiklik olmaktadır. Ayak üzeri hızlı atıştırma ve yağ, şeker ve tuzdan zengin olan "fast food" alışkanlıkları ya da öğün atlama artmaktadır. Beslenme,

Yazışma Adresi/Address for Correspondence: Dr. Tülay Erkan, İstanbul Üniversitesi Cerrahpaşa Tıp Fakültesi, Çocuk Gastroenteroloji, Hepatoloji ve Beslenme Bilim Dalı, İstanbul, Türkiye E-mail: erkan01@istanbul.edu.tr Türk Pediatri Arşivi Dergisi, Galenos Yayınevi tarafindan basılmıştır. / Turkish Archives of Pediatrics, Published by Galenos Publishing 
büyüme ve gelişmenin sürdürülmesi ve sağlığın korunmas için gereklidir. Beslenme çocukluk ve ergenlik döneminde yeterli ve dengeli olmazsa, ileri dönemlerde önemli kronik hastalıkların oluşmasına zemin hazırlayabilir (2). Hayat boyu sürecek beslenme alışkanlıkları ergenlik döneminde yerleşir. Bu önemli dönemde kötü beslenme alışkanlıkları ve beslenme bozuklukları daha sıktır (3). Genelde beslenme şekli ve içeriği yaşam şekli ve koşullarıyla koşutluk gösterir. Ergenlik döneminde yetersiz beslenme ya da kötü beslenme alışkanlıkları sonucunda ileriki yıllarda osteoporoz, şişmanlık, hiperlipidemi, cinsel gelişimde gecikme, kalp-damar hastalıkları ve kanser önemli sorun olarak karşımıza çıkar $(2,4-7)$.

\section{Ergen beslenmesini değerlendirirken göz önünde bulundurulması gereken noktalar şunlardır:}

- Boy-ağırlık ölçümü alınmalı ve önceki değerleri ile karşılaştııımalıdır. Herhangi bir kilo kaybı, aşıı kilo alımı ve büyümede gecikme varsa kaydedilmelidir.

- Fiziksel etkinlik sorgulanmalıdır.

- Gün içindeki öğün sayısı ile öğünlerdeki yemeğin niteliği ve niceliği belirtilmelidir.

- Cinsel gelişme ve "menstrüasyon” öyküsü alınmalıdır.

Bilinmelidir ki yeme bozuklukları, alkol ya da ilaç kullanımı, kronik hastalık nedeniyle sürekli ilaç alımı, çok sıkı bir vejetariyen diyet ve düşük sosyo-ekonomik düzey beslenme yetersizliğinin oluşmasında rol oynayan etmenlerdir (8).

Ergen beslenmesini değerlendirirken normal koşullarda günlük alması gereken miktarların bilinmesi gerekir. Dolayısıyla günlük beslenme şekli ve içeriği öyküde mutlaka sorgulanmalıdır.

\section{Ergenin besin gereksinimleri}

\section{Kalori}

Büyüme ve etkinlik için ek enerjiye gereksinim vardır. 11-18 yaş arasındaki erkeklerin günde yaklaşık 2500-2800 kalori, kızların ise 2200 kalori almaları gerekmektedir. Bu miktarlarda çocukluk dönemine göre oldukça önemli bir artış vardır. Yarışmalı spor dallarına katılan ya da fiziksel etkinliği fazla olan ergenlerin enerji gereksinimi bu ortalamalarda daha da yüksektir. Bunun karşılanabilmesi için ergenlerin çeşitli protein kaynaklarını, düşük yağlı süt ürünlerini, sebze ve meyveleri tüketmeleri gerekmektedir. Bu dönemdeki enerji ve besin eksikliği pubertenin gecikmesine ve büyümenin geri kalmasına neden olmaktadır. Yetersiz enerji alımı ise sıkı diyet yapılması, düşük ekonomik düzey ya da kronik hastalık ile ilişkili olabilir.

\section{Protein}

Protein kas gelişimi ve devamlılığı, hücre onarımı için gereklidir. Protein gereksinimi çocukluk ve ergenlikte, gebelikemzirme döneminde, hastalık ya da cerrahi girişim sonrasında artar. Ergenlerin günlük intiyacı yaklaşık 45-60 gr'dır (Tablo 1). Kızlarda 0,8 g/kg/gün, erkeklerde $1 \mathrm{~g} / \mathrm{kg} / \mathrm{gün}$ bu gereksinimi karşılamaktadır. Büyüme için gerekli protein miktarı kızlarda 11-14 yaş arasında, erkeklerde 15-18 yaş arasında daha fazladır. Ergenlerin çoğu bu miktarı et, tavuk, yumurta ve sütlü ürünler alarak karşılayabilir. Ayrıca soya, taneli tahıllar ve fındık gibi et dışı ürünler de buna katkıda bulunur. Yeterli protein alınamadığında lineer büyümede, cinsel olgunlaşmada gerilik ve yağsız vücut kütlesinde azalma görülür. Yeterli karbonhidrat alınamadığında ise protein, enerji kaynağı olarak da kullanılır.

\section{Karbonhidrat}

En önemli enerji kaynağıdır. Meyve, sebze, tüm taneli tahıllar gibi karbonhidrattan zengin gıdalar aynı zamanda diyetteki önemli lif kaynaklarıdır. Günlük toplam kalorinin \%50-60’ı karbonhidratlardan sağlanmalıdır. Ancak sükroz, früktoz gibi tatlandıııcılar kalorinin \%10-25'ini geçmemelidir.

Yağ

Normal büyüme ve gelişme için yağ ve yağ asitlerine gereksinim vardır. Yağlar toplam kalorinin \%30'unu, doymuş yağ asitleri de \%10'unu geçmemelidir. Günlük 2200 kalori alacak ergen için $73 \mathrm{~g} /$ gün, 2800 kalori alacak ergen içinse $93 \mathrm{~g} /$ gün yağ alımı uygundur.

\section{Mineraller}

\section{Kalsiyum}

Kemik kütlesinin \%45’i ergenlik döneminde oluştuğundan, bu dönemde uygun miktarda kalsiyum almak çok önemlidir (Tablo 2). Bu dönemde yeterli kalsiyum alınamaması ileri dönemde osteoporoz gelişimine yol açar (9). Günde yaklaşık

Tablo 1. Ergenlerde günlük alınması gereken besin miktarları

\begin{tabular}{|l|c|c|c|c|}
\hline & \multicolumn{2}{|c|}{ Kız } & \multicolumn{2}{c|}{ Erkek } \\
\hline & $9-13$ yaş & $14-18$ yaş & $9-13$ yaş & $14-18$ yaş \\
\hline Enerji kcal/gün) & 2,071 & 2,368 & 2,279 & 132 \\
\hline Karbohidrat gr/gün) & 130 & 130 & 12 & 130 \\
\hline Omega-6 yağ (gr/gün) & 10 & 11 & 1,2 & 1,6 \\
\hline Omega-3 yağ (gr/gün) & 1,0 & 1,1 & 34 & 52 \\
\hline Protein (gr/gün) & 34 & 46 & 31 & 38 \\
\hline Lif (gr/gün) & 26 & 28 & & 32 \\
\hline
\end{tabular}


1200 mg kalsiyum alımının sağlanabilmesi için ergenlerin her gün 3-4 defa kalsiyumdan zengin gıda alması önerilmektedir. Süt, yoğurt, peynir ve kalsiyum ile zenginleștirilmiş meyve suları ve tahıllar bu açıdan değerlidir. Erkeklerin her yaş döneminde günlük kalsiyum gereksinimi kızlardan daha fazladır. Diyetle yeterli alınamıyorsa kalsiyumun diyete eklenmesi gerekir. Kimyasal şekillerinin (kalsiyum karbonat, sitrat, laktat ya da fosfat) ancak \%25-35'i emilebilmektedir. Bunlar içinde kalsiyum karbonat hem emilebilirliği en yüksek olan (\%40), hem de fiyatı en ucuz olandır (10). Ek olarak verilen kalsiyum eğer yemeklerle birlikte ve en fazla 500 mg olacak şekilde verilirse emilebilirliği en yüksek olmaktadır.

\section{Demir}

Ergenlik döneminde kas kütlesi arttı̆ı̆ından, yeni kas hücrelerinin enerji için gerekli oksijeni sağlayabilmeleri için daha fazla demire gereksinimleri vardır. Dolayısıyla bu dönemde gerek demir, gerekse D vitamini eksikliğine sık rastlanır (11). Günlük demir gereksinimi erkeklerde günde 12 mg, kızlarda 15 mg'dır. Et, tavuk, yeşil sebzeler önemli demir kaynaklarıdır. Bitkisel ürünlerdeki demirin emilimi daha düşük olduğu için vejetariyenler günlük demir gereksinimlerini karşılayabilmek için en az normalden iki kat daha fazla demir almak zorundadırlar (12).

\section{Çinko}

Çinko bedende 100'den fazla enzimin yapısına girmektedir ve gerek protein oluşumu gerekse gen "ekspresyon"unda yaşamsal değeri vardır. Büyüme ve cinsel gelişimdeki rolü nedeniyle ergenler için önemlidir. Ergen kızların \%18-33'ünde orta derecede çinko eksikliği $(<10,71 \mu \mathrm{mol} / \mathrm{L})$ saptanmıştır (13). 9-13 yaşındaki kız-erkek ergenlerin çinko gereksinimi günde 8 mg'dır. 14-18 yaş arasındaki erkeklerin gereksinimi günde 11 mg, kızların 9 mg'dır. "Continuing Survey of Food Intakes by Indıviduals" (CSFII) verilerine göre ergenlerin yaklaşık 1/3'inde çinko alımı yeterli değildir (14). Kırmızı et, balık ve tüm taneli hububat çinko açısından zengindir.

\section{Vitaminler}

Beden sağlığının korunmasında vitaminler de önemli rol oynar. Sağlıkı bir beslenme uygulandığında normalde gerekli vitamin alımı sağlanır. Vitaminler yağda eriyenler $(A, D, E, K)$ ve suda eriyenler $\left(B_{1}, B_{2}, B_{3}, B_{5}, B_{6}, B_{12}\right.$, folik asit, biyotin ve $C$ vitamini) olmak üzere ikiye ayrılır. Yağda eriyenler bedende depolandıkları için aşırı alınmaları toksisiteye neden olabilir. Asında nöral tüp bozukluklarını engellediği bilinen folatın gebelik öncesi verilmesi dışında, diğer vitaminlerin sağlıklı beslenmede dışarıdan verilmesine gerek yoktur.

\section{A vitamini}

Normal görmeyi sağlaması yanında, A vitamininin üreme, büyüme ve bağışıklık işlevlerinde de yaşamsal rolü vardır. Bedenin yeterli A vitamini deposunun sağlanabilmesi için 9-13 yaş arasındaki kız ve erkeklerin günde $600 \mu \mathrm{g}$, 14-18 yaş arasındaki kızların $700 \mu \mathrm{g}$, erkeklerin $900 \mu \mathrm{g} \mathrm{A}$ vitaminin tüketmeleri gerekmektedir (Tablo 3). CSFII gözlemine göre ergenlerin \%30'u yeterli A vitamini almamaktadırlar (14). Tahıl, süt, havuç, margarin ve peynir en önemli A vitamini kaynaklarıdır (15).

\section{D vitamini}

Gerek Ca dengesinin sağlanması, gerekse iskelet sisteminin bütünlüğünün korunması açısından önemlidir. Ancak bunun dışında hücre farklılaşması ve çoğalmasında, hücre büyümesinde, hormon salgılanmasında da önemli rol oynar (16). Ayrıca kan basıncı yüksekliği, diyabet, kanser, kardiyovasküler hastalıklar ve immün sistem bozuklukları gibi birçok kronik hastalıkta da D vitamini eksikliği saptanmıştır (17). D vitamininin kandaki en iyi göstergesi serum $25(\mathrm{OH})$ D düzeyidir. Düzeyi konusunda tam bir birliktelik oluşmamış olmasına karşın, $10-15 \mathrm{ng} / \mathrm{mL}$ 'nin altında olması D vitamini eksikliği olarak kabul edilmektedir (17). Günde 400 IU alınmalıdır. Ergenlerin yaklaşık \%14'ünde eksikliği bildirilmiştir (18).

Tablo 2. Ergenlerde günlük alınması gereken mineral miktarlar

\begin{tabular}{|c|c|c|c|c|}
\hline & \multicolumn{2}{|c|}{$\mathbf{K} \mathbf{z}$} & \multicolumn{2}{|c|}{ Erkek } \\
\hline & 9-13 yaş & 14-18 yaş & 9-13 yaş & 14-18 yaş \\
\hline Kalsiyum (mg/gün) & 1300 & 1300 & 1300 & 1300 \\
\hline Krom ( $\mu \mathrm{g} / \mathrm{gün})$ & 21 & 24 & 25 & 35 \\
\hline 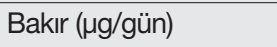 & 700 & 890 & 700 & 890 \\
\hline Flor (mg/gün) & 2 & 3 & 2 & 3 \\
\hline İyot ( $\mu \mathrm{g} / \mathrm{gün})$ & 120 & 150 & 120 & 150 \\
\hline Demir (mg/gün) & 8 & 15 & 8 & 11 \\
\hline Magnezyum (mg/gün) & 240 & 360 & 240 & 410 \\
\hline Manganez (mg/gün) & 1,6 & 1,6 & 1,9 & 2,2 \\
\hline Molibden ( $\mu \mathrm{g} / \mathrm{gün})$ & 34 & 43 & 34 & 43 \\
\hline Fosfor (mg/gün) & 1250 & 1250 & 1250 & 1250 \\
\hline Selenyum ( $\mu \mathrm{g} / \mathrm{gün})$ & 40 & 55 & 40 & 55 \\
\hline Çinko (mg/gün) & 8 & 9 & 8 & 11 \\
\hline
\end{tabular}




\section{E vitamini}

Vitamin E özellikle antioksidan özellikleri nedeniyle önemlidir. Günlik E vitamini gereksinimi 9-13 yaș arasında $11 \mathrm{mg}, 14-18$ yaş arasında $15 \mathrm{mg}$ 'dır (Tablo 3). CSFII gözlemlerine göre ergenlerin \%40'ının günlük $E$ vitamini tüketimi olması gerekenden azdır (14). E vitamini kaynaklarının çoğu yağlı gıdalardır. Ergenlere vitaminle desteklenmiş tahıllar ve fındık özellikle önerilmektedir.

\section{$C$ vitamini}

C vitamini kolajen ve diğer bağ dokularının sentezi için gerekli bir vitamindir. Günlük alınması gereken miktar 9-13 yaș arasında $45 \mathrm{mg}, 14-18$ yaș arasındaki erkekler için 75 $\mathrm{mg}$, kızlar için $65 \mathrm{mg}$ 'dır (Tablo 3). Genelde ergenlerin \%86-98'i uygun miktarda C vitamini tüketmektedir. Sigara oksidatif stresi ve $\mathrm{C}$ vitamininin metabolik döngüsünü artırdığı için, sigara içenlerin $\mathrm{C}$ vitamini düzeyi içmeyenlere göre daha düşüktür. Bu nedenle sigara içenlerin günde $35 \mathrm{mg}$ daha fazla C vitamini almaları gerekmektedir (19). Sigara içen ergenlerin beslenme düzenleri de daha kötü olduğu ve daha az sebze ve meyve tükettikleri için, C vitamini düzeyleri de daha düşüktür.

\section{Folat}

Folatlar DNA, RNA ve protein sentezinde rol oynarlar. Günlük folat gereksinimi 9-13 yaş arasındaki ergenler için $300 \mu \mathrm{g}, 14-18$ yaş arasındakiler için $400 \mu \mathrm{g}$ 'dır (Tablo 3). Sabah kahvaltısı yapma alışkanlı̆̆ı olmayan ya da hiç portakal suyu ya da hububat tüketmeyen ergenler özellikle folat eksikliği açısından risk grubundadırlar.

\section{Diğer}

\section{Lifler}

Diyette lifin yeterli düzeyde bulunması normal bağırsak alışkanlığı açısından önemli olduğu gibi, bazı kronik hasta-
Iıkların önlenmesinde de rol oynayabilir. Ayrıca serum kolesterol düzeylerinin düşürülmesinde, şişmanlık riskinin azaltılmasında da rol oynayabilir. Genelde çocuklarda günlük lif alımı yaş +5 kuralına göre ayarlanmaktadır (20). Üst sınır ise yaş +10 'dur. Genelde okullarda sağlıklı bir beslenme ortamı sunmadan diyetteki lif oranını artırmak çok mümkün olmamaktadır (21).

Ergenlerdeki fiziksel değişikliklerin beslenmeleri üzerine doğrudan bir etkisi vardır. Dolayısıyla ergenlerin ek kalori, protein, kalsiyum ve demire gereksinimleri vardır. Ancak Amerika Birleşik Devletleri'nde yapılan bir çalışmada ergenlerin günlük beslenmelerinde toplam yağ, doymuş yağ, sodyum, kolesterol ve şekeri gerektiğinden fazla tükettikleri, vitaminlerden folat, $\mathrm{A}, \mathrm{E}, \mathrm{B} 6$ 'yı, minerallerden kalsiyum, demir, çinko ve magnezyum ile lifi gerektiğinden az tükettiği saptanmıştır (2).

Sağlıklı bir ergen beslenmesi için: sebze, meyve, tüm taneli tahıllar çok miktarda, az yağlı süt ürünleri ve yağsız et orta miktarda, yağ, şeker ve tuzdan zengin gıdalar çok az miktarda tüketilmeli ve her gün bol su içmek alışkanlık haline getirilmelidir.

Her grup besini içeren sağlıklı bir diyet ile birlikte düzenli yapılan fizik egzersiz ergenlerin sağlıklı büyüme ve gelişmesini sağlıyacaktır. Așırı televizyon izlenmesi azaltılarak bile ergenlerdeki karın yağlanmasının azaltılması sağlanabilir (22). Beslenmeye yaşamın her döneminde gereken önemi vermeliyiz. Özellikle günümüzde erişkinin önemli sağlık sorunlarından olan şişmanlık, osteoporoz ve kalp-damar hastalıklarının çocukluk ve ergenlik dönemindeki yanlış beslenme uygulamalarının sonucu olduğunu unutmamak gerekir.

Tablo 3. Ergenlerde günlük alınması gereken vitamin miktarları

\begin{tabular}{|c|c|c|c|c|}
\hline & \multicolumn{2}{|c|}{$\mathbf{K} \mathbf{z}$} & \multicolumn{2}{|c|}{ Erkek } \\
\hline & 9-13 yaş & 14-18 yaş & 9-13 yaş & 14-18 yaş \\
\hline A vitamini ( $\mu \mathrm{g} / \mathrm{gün})$ & 600 & 700 & 600 & 900 \\
\hline C vitamini (mg/gün) & 45 & 65 & 45 & 75 \\
\hline D vitamini ( $\mu \mathrm{g} / \mathrm{gün})$ & 5 & 5 & 5 & 5 \\
\hline E vitamini (mg/gün) & 11 & 15 & 11 & 15 \\
\hline K vitamini ( $\mu \mathrm{g} / g u ̈ n)$ & 60 & 75 & 60 & 75 \\
\hline Tiyamin (mg/gün) & 0,9 & 1,0 & 0,9 & 1,2 \\
\hline Riboflavin (mg/gün) & 0,9 & 1,0 & 0,9 & 1,3 \\
\hline Niyasin (mg/gün) & 12 & 14 & 12 & 16 \\
\hline B6 vitamini (mg/gün) & 1,0 & 1,2 & 1,0 & 1,3 \\
\hline 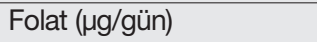 & 300 & 400 & 300 & 400 \\
\hline B12 vitamini ( $\mu \mathrm{g} / \mathrm{gün})$ & 1,8 & 2,4 & 1,8 & 2,4 \\
\hline Pantotenik asit (mg/gün) & 4 & 5 & 4 & 5 \\
\hline Biyotin ( $\mu \mathrm{g} / \mathrm{gün})$ & 20 & 25 & 20 & 25 \\
\hline Kolin (mg/gün) & 375 & 400 & 375 & 550 \\
\hline
\end{tabular}




\section{Kaynaklar}

1. Demirezen E, Coşansu G. Adolesan çağı öğrencilerde beslenme alışkanlıklarının değerlendirilmesi. Sted 2005; 8: 174-8. (PDF)

2. Guidelines for Adolescent Nutrition Services. Stang J, Story M ed (s). 2005. http://www.epi.umn.edu/Irt/pubs/adol_book.shtm. (erişim tarihi: 10.10.2010). (Full Text)

3. Gonzales A, Kohn MR, Clarke SD. Eating disorders in adolescents. Australian Family Physician 2007; 36: 614-9.

4. Wang MC, Crawford PB, Hudes M, Van Loan M, Siemering K, Bachrach LK. Diet in mid-puberty and sedentary activity in pre-puberty predicting peak bone mass. Am J Clin Nutr 2003; 77: 495-503. (Abstract) / (Full Text) / (PDF)

5. Feldman S, Eisenberg ME, Neumark-Sztainer D, Story M. Associations between watching TV during family meals and dietary intake among adolescents. J Nutr Educ Behav 2007; 39: 257-63. (Abstract) / (Full Text) / (PDF)

6. Powell LM, Szczypka G, Chaloupka FJ, Braunschweig CL. Nutritional content of television food advertisements seen by children and adolescents in the United States. Pediatrics 2007; 120: 576-83. (Abstract) / (Full Text) / (PDF)

7. McNaughton SA, Ball K, Mishra GD, Crawford DA. Dietary patterns of adolescents and risk of obesity and hypertension. J Nutr 2008; 138: 364-70. (Abstract) / (Full Text) / (PDF)

8. Langevin DD, Kwiatkowski C, McKay MG, et al. Evaluation of diet quality and weight status of children from a low socioeconomic urban environment supports "at risk" classification. J Am Diet Assoc 2007; 107: 1973-7. (Abstract) / (Full Text) / (PDF)

9. American Academy of Pediatrics. Committee on Nutrition. Calcium requirements of infants, children, and adolescents. Pediatrics 1999; 104: 1152-7. (Abstract) / (Full Text) / (PDF)

10. Levenson DI, Bockman RS. A review of calcium preparations. Nutr Rev 1994; 52: 221-32. (Abstract)
11. Steinbeck K. Obesity and nutrition in adolescents. Adolesc Med State Art Rev 2009: 20: 900-14. (Abstract)

12. Russell RM. New micronutrient dietary reference intakes from the National Academy of Sciences. Nutr Today 2001; 36 : 163-71. (Full Text)

13. Donovan UM, Gibson RS. Iron and zinc status of young women aged 14 to 19 years consuming vegetarien and omnivorous diets. J Am Coll Nutr 1995; 14: 463-72. (Abstract)

14. US Department of Agriculture, Agricultural Research Service. Continuing Survey of Food Intakes by Individuals (CSFII) and the Diet and Health Knowledge Survey (DHKS) 1994-6. (PDF)

15. Subar AF, Krebs-Smith SM, Cook A, Kahle LL. Dietary sources of nutrients among US children, 1989-1991. Pediatrics 1998; 102: 913-23. (Abstract) / (Full Text) / (PDF)

16. Holick MF. Sunlight and vitamin D for bone health and prevention of autoimmune diseases, cancers and cardiovascular disease. Am J Clin Nutr 2004; 80: 1678-88. (Abstract) / (Full Text) / (PDF)

17. Rowner AJ, O'brien KO. Hypovitaminosis D along healthy children in the United States. Arch Pediatr Adolesc Med 2008; 162: 513-9. (Abstract) / (Full Text) / (PDF)

18. Saintonge $\mathrm{S}$, Bang $\mathrm{H}$, Gerber LM. Implication of new definition of vitamin $D$ deficiency in a multiracial US adolescent population: the National Health and Nutrition Examination Survey III. Pediatrics 2009; 123: 797-803. (Abstract) / (Full Text) / (PDF)

19. Garriguet D. The effect of supplement use on vitamin C. Health Reports 2010; 21: 1-6. (PDF)

20. Williams CL, Bollella M, Wynder EL. A new recommendation for dietary fiber in childood. Pediatrics 1995; 96: 985-8.

21. Hoppu U, Lehtisalo J, Kujala J, et al. The diet of adolescents can be improved by school intervention. Public Health Nutr 2010; 13: 973-9. (Abstract)

22. Martinez-Gomez D, Rey-Lopéz JP, Chillón P, et al. Excessive TV viewing and cardiovascular disease risk factors in adolescents. The AVENA cross-sectional study. BMC Public Health 2010; 10: 274. (Abstract) / (Full Text) / (PDF) 